\title{
Myocardial Injury after Electric Accident: Dynamic Change of Cardiac Biomarkers Was the Important Key for Diagnosis of This Serious Complication
}

\author{
Le Ngoc Hung ${ }^{1,2}$, Truong Duong Tien ${ }^{1,2}$ \\ ${ }^{1}$ Biochemistry Department, Cho Ray Hospital, Ho Chi Minh City, Vietnam \\ ${ }^{2}$ Cho Ray-Phnom Penh Hospital, Phnompenh, Cambodia \\ Email: lengochungan@yahoo.com
}

Received 28 January 2015; accepted 13 July 2015; published 16 July 2015

Copyright (C) 2015 by authors and Scientific Research Publishing Inc.

This work is licensed under the Creative Commons Attribution International License (CC BY). http://creativecommons.org/licenses/by/4.0/

\begin{abstract}
This report was aimed to record the value of dynamic change of cardiac biomarkers in diagnosis of serious myocardial injury in electrical shock. One female patient was admitted to the emergency department, Cho Ray-Phnom Penh Hospital, Phnom Penh, Cambodia after electrical accident, in cardiopulmonary arrest status with no pulse, no breath. The cardiopulmonary resuscitation was done immediately as intra-tracheal ventilation, fluid replacement with $\mathrm{NaCl} 0.9 \%$, urine alkalinization therapy with Natribicarbonate $4.2 \%$, sympathomimetic agents as adrenaline and nor-adrenaline, and IV nutrition with glucose $30 \%$. Cardiac biomarkers were repeated many times over 12 hours after admission. Troponin I increased 1000 times higher from $0.02 \mathrm{ng} / \mathrm{mL}$ on admission to $20.1 \mathrm{ng} / \mathrm{mL}$ within 12 hours. CK-MB increased from 55.4 to $227 \mathrm{U} / \mathrm{L}$ after 2 hours (normal value: $<16 \mathrm{U} / \mathrm{L}$ ). CPK (normal value: 90 - $140 \mathrm{U} / \mathrm{L}$ ) changed quickly from $99 \mathrm{U} / \mathrm{L}$ on admission to a very high level as $9681 \mathrm{U} / \mathrm{L}$ after $12 \mathrm{hrs}$. The CK-MB/CPK index (defined as CK-MB × 100/CPK, unit as \%) changed from $55.9 \%$ to $2.7 \%$, respectively by time. In conclusion, the very quick dynamic change of cardiac biomarkers suggested the presence of serious myocardial injury among multiple organs injured in electric shock.
\end{abstract}

\section{Keywords}

Serious Myocardial Injury, Electric Shock, Troponin I, Dynamic Change, Cardiac Biomarkers

\footnotetext{
${ }^{*}$ Corresponding author.

How to cite this paper: Hung, L.N. and Tien, T.D. (2015) Myocardial Injury after Electric Accident: Dynamic Change of Cardiac Biomarkers Was the Important Key for Diagnosis of This Serious Complication. Journal of Biosciences and Medicines, $\mathbf{3}$, 78-81. http://dx.doi.org/10.4236/jbm.2015.37009
} 


\section{Introduction}

Troponin has been used as the critical biomarker of the presence of myocardial necrosis in the diagnosis of myocardial infarction. However, myocardial necrosis is not always due to atherosclerotic coronary artery disease. There are many other causes of myocardial injury such as myocarditis, cardiac trauma, cardiac surgery or cardioversion. These reasons may also cause myocardial necrosis and release of troponins. However, electrical causes of myocardial necrosis may be still questionable. There are many controversial evidences about this point. Cardiac troponin $\mathrm{T}$ was reported as not increase after electrical cardioversion for atrial fibrillation or atrial flutter [1]. Cardioversion can lead to mild cTnI rise as measured with a high-sensitivity assay [2]. There was no evidence of myocytes injury, no increase of troponin I after external electrical direct current synchronized cardioversion in patients with normal or reduced ejection fraction [3]. It was rare for electrical injury case with serious myocardial damage and death. [4]. We reported hereinafter a special case with such setting.

\section{Case Report}

A female worker, 56 years old, had an electrical accident when working in a construction field during the rain. She was transferred immediately, around 20 minutes, from the working site to the hospital with the status as no breathing, no pulse. The body temperature was low as $36^{\circ} \mathrm{C}$, blood pressure could not be measured. The Glasgow Coma Scale was 5 (eye: 3, verbal: 1 , motor: 1 ). The cardiopulmonary resuscitation was done immediately as intratracheal ventilation, fluid replacement with $\mathrm{NaCl} 0.9 \%$, urine alkalinization therapy with Natribicarbonate $4.2 \%$, sympathomimetic agents as adrenaline and nor-adrenaline, and IV nutrition with glucose $30 \%$. The biochemistry tests were presented in Table 1.

The main change in biochemistry tests was the quickly increase of troponin I around 1000 times higher from normal value as $0.02 \mathrm{ng} / \mathrm{mL}$ on admission to $20.1 \mathrm{ng} / \mathrm{mL}$ within 12 hours. CK-MB increased faster from 55.4 to $227 \mathrm{U} / \mathrm{L}$ after 2 hours (normal value: <16 U/L). CPK (normal value: 90 - $140 \mathrm{U} / \mathrm{L}$ ) was changed quickly from normal value as $99 \mathrm{U} / \mathrm{L}$ on admission to a very high level as $9681 \mathrm{U} / \mathrm{L}$ after $12 \mathrm{hrs}$. The CK-MB/CPK index

Table 1. The change of biochemistry tests in patient with electrical injury.

\begin{tabular}{|c|c|c|c|c|c|}
\hline Parameters & & & Results & & \\
\hline Time (counting from the administration) & 0:00:00 & 2:09:00 & $10: 24: 00$ & 12:58:00 & $17: 50: 00$ \\
\hline Troponin I (ng/ml) & 0.02 & 0.89 & & 20.1 & \\
\hline Serum Creatinin (mg/dL) & 1.15 & 1.52 & & 2.23 & \\
\hline eGFR-MDRD (ml/min/1.73 m²) & 51.5 & 37.3 & & 23.88 & \\
\hline AST (U/L) & 593 & 1516 & & 1208 & \\
\hline $\operatorname{ALT}(\mathrm{U} / \mathrm{L})$ & 435 & 831 & & 861 & \\
\hline CK-MB (U/L) & 55.4 & 227 & & 260 & \\
\hline CPK (U/L) & 99 & & & 9681 & \\
\hline CK-MB/CPK index (\%) & 55.9 & & & 2.7 & \\
\hline Myoglobin (ng/mL) & & & & 18,106 & \\
\hline $\mathrm{RBC}(\mathrm{T} / \mathrm{L})$ & 4.68 & 4.68 & & 3.88 & \\
\hline WBC $\left(10^{3} / \mu \mathrm{L}\right)$ & 12.25 & 37.3 & & 26.39 & \\
\hline INR & NA & 1.74 & & & \\
\hline PT & NA & 16.9 & & & \\
\hline $\mathrm{pH}$ & NA & 7.32 & 7.18 & & 7.21 \\
\hline $\mathrm{pCO}_{2}(\mathrm{mmHg})$ & & 32.4 & 27.3 & & 22.8 \\
\hline $\mathrm{HCO}_{3}^{-}(\mathrm{mmol} / \mathrm{L})$ & & 16.7 & 10.1 & & 9 \\
\hline
\end{tabular}


(defined as CK-MB $\times 100 / \mathrm{CPK}$, unit as \%) changed from $55.9 \%$ to $2.7 \%$, respectively by time. The serum creatinine was high on admission, $1.15 \mathrm{mg} / \mathrm{dL}$ and thereafter increased more than $1 \mathrm{mg} / \mathrm{dL}$ to become $2.23 \mathrm{mg} / \mathrm{dL}$; inversely the values of eGFR-MDRD were reduced. The value of myoglobin in serum was very high as 18,106 $\mathrm{ng} / \mathrm{ml}$ (normal: $<85 \mathrm{ng} / \mathrm{mL}$ ). Electrocardiogram was not done. Urine output was around 1 liter with dark yellow color, but urinalysis was not done. Patient was in no pulse, no breath on admission with severe metabolic acidosis. Patient changed to the tachycardia (127 pulses/min) after resuscitation and under the support of cardiovascular vasopressor agents. However, the patient died around 24 hours after hospital administration.

\section{Discussion}

In this patient, the value of CK-MB increased quickly within 2 hours from 55 to $227 \mathrm{U} / \mathrm{l}$, suggesting the main source of CK-MB may be from heart injury. The CK-MB/CPK index changed from $55.9 \%$ to $2.7 \%$ indicating that heart, the main source of CK-MB, may be the first, major muscle tissue injured, but thereafter other organs as muscles, brain, kidney, lung, may also release both CPK and CK-MB to the circulation. However, both dynamic changes in CK-MB and CK-MB/CPK index suggested heart was the one among other organs injured by current. The extremely elevated CPK as $9681 \mathrm{U} / \mathrm{L}$ suggested patient with massive striated muscle damage from highvoltage injuries. Troponin has been used absolutely as biomarker of heart necrosis. An abruptly increase of troponin I from 0.02 to 0.89 and thereafter $20.1 \mathrm{ng} / \mathrm{ml}$ within 12 hours confirmed that the heart was injured. This quick dynamic change of troponin I could not be seen in the rupture of atherosclerotic coronary artery, leading to tissue necrosis in myocardial infarction. The quick and high value of troponin I may indicate the large diffuse nature of myocardial necrosis in the heart. Patient also had the acute renal failure from electrical injury with high value of myoglobin 18,106 $\mathrm{ng} / \mathrm{ml}$, this showed the presence of severer habdomyolysis, and the eGFR reduced rapidly from 51.5 to $23.8 \mathrm{ml} / \mathrm{min} / 1.73 \mathrm{~m}^{2}$ [5] [6]. This acute renal failure may also contribute a part in the increase of troponin I.

The direct trauma to heart may cause the increase of troponin. A significant correlation between clinical inflammation associated parameter (IAPs) and cTnI plasma level elevation was found after cardiac surgery [7]. Cardiac troponin I (cTnI) was reported as a sensitive and specific marker for postoperative myocardial infarction in patients after coronary artery bypass surgery (CABG) [8].

Electrical injury of cardiomyocytes after cardioversion can lead to mild cTnI rise, $0.04 \mathrm{ng} / \mathrm{ml}$ higher than before, $0.017 \mathrm{ng} / \mathrm{ml}$, as measured with a high-sensitivity assay [2]. Myocardial injury is caused directly by electrothermal conversion and electroporation or secondarily by contusion following a lightning strike [6]. The diagnosis of myocardial injury due to electrical injury was often difficult (because of the diffuse nature of myocardial necrosis), due to the absence of typical symptoms, lack of special ECG changes [9]. The value of CK-MB and troponin in this setting were unknown [10]. Celebi, A. (2009) reported a rare electric shock case with myocardial infarction having high value of CK, CK-MB and troponin I as $7150 \mathrm{U} / \mathrm{L},>400 \mathrm{U} / \mathrm{L}$ and $24 \mathrm{ng} / \mathrm{ml}$, and ECG findings suggesting inferior myocardial infarction, patient survived after the accident [11]. In our case, the findings for myocardial injury were combining with arrhythmia, no pulse, suggesting the diffuse injuries more than local necrosis in the heart.

The lack of ECG recording in this case, so the cause of arrhythmia, no pulse, was not clear. Ventricular fibrillation was common with low-voltage alternating current and asystole was in shocks from high-voltage one [12] [13].

Sudden cardiac death was more common in electrical shock cases presenting cardiopulmonary arrest [14]. Mortality was reported as 59\% in electrical injury patients with acute renal failure, especially with rhabdomyolysis [5]. Mortality of electrical injury was reported as $8.06 \%$ in retrospective study of Guntheti BK in 62 patients at Mamata General Hospital, Khammam, India, in 2007-2008 [15].

\section{Conclusion}

In conclusion, this report presented an electrical injury case with rapidly dynamic change in cardiac biomarkers, mainly in troponin I, suggesting the whole, serious diffuse damage of myocardial tissue. Repeat measurements of CPK, CK-MB, especially troponin I, were very important to evaluate the dynamic change in myocardial tissue due to electric current. This dynamic change had values both in diagnosis of myocardial injury and prediction of the patient prognosis. 


\section{Conflict of Interest}

The authors do not report any conflict of interest regarding this work.

\section{References}

[1] Greaves, K. and Crake, T. (1998) Cardiac Troponin T Does Not Increase after Electrical Cardioversion for Atrial Fibrillation or Atrial Flutter. Heart, 80, 226-228. http://dx.doi.org/10.1136/hrt.80.3.226

[2] Piechota, W., Gielerak, G., Ryczek, R., Kaźmierczak, A., Bejm, J. and Piechota, W. (2007) Cardiac Troponin I after External Electrical Cardioversion for Atrial Fibrillation as a Marker of Myocardial Injury-A Preliminary Report. Kardiologia Polska, 65, 664-669.

[3] Cemin, R., Rauhe, W., Marini, M., Pescoller, F. and Pitscheider, W. (2005) Serum Troponin I Level after External Electrical Direct Current Synchronized Cardioversion in Patients with Normal or Reduced Ejection Fraction: No Evidence of Myocytes Injury. Clinical Cardiology, 28, 467-470. http://dx.doi.org/10.1002/clc.4960281005

[4] John, B.A., Bena, J.F., Stayner, L.T., Halperin, W.E. and Park, R.M. (2003) External Cause Specific Summaries of Occupational Fatal Injuries. Part I: An Analysis of Rates. American Journal of Industrial Medicine, 43, $237-250$. http://dx.doi.org/10.1002/ajim.10184

[5] Haberal, M.A. (1995) An Eleven-Year Survey of Electrical Burn Injuries. Journal of Burn Care \& Rehabilitation, 16, 43-48. http://dx.doi.org/10.1097/00004630-199501000-00008

[6] Rosen, C.L., Adler, J.N., Rabban, J.T., Sethi, R.K., Arkoff, L., Blair, J.A., et al. (1999) Early Predictors of Myoglobinuria and Acute Renal Failure Following Electrical Injury. The Journal of Emergency Medicine, 17, 783-789. http://dx.doi.org/10.1016/S0736-4679(99)00084-0

[7] Knayzer, B., Abramov, D., Natalia, B., Tovbin, D., Ganiel, A. and Katz, A. (2007) Atrial Fibrillation and Plasma Troponin I Elevation after Cardiac Surgery: Relation to Inflammation-Associated Parameters. Journal of Cardiac Surgery, 22, 117-123. http://dx.doi.org/10.1111/j.1540-8191.2006.00366.X

[8] Thielmann, M., Massoudy, P., Neuhäuser, M., Knipp, S., Kamler, M., Marggraf, G., Piotrowski, J. and Jakob, H. (2005) Risk Stratification with Cardiac Troponin I in Patients Undergoing Elective Coronary Artery Bypass Surgery. European Journal Cardio-Thoracic Surgery, 27, 861-869. http://dx.doi.org/10.1016/j.ejcts.2005.01.043

[9] Housinger, T.A., Green, L., Shahangian, S., Saffle, J.R. and Warden, G.D. (1985) A Prospective Study of Myocardial Damage in Electrical Injuries. Journal of Trauma-Injury Infection \& Critical Care, 25, 122-124. http://dx.doi.org/10.1097/00005373-198502000-00005

[10] Spies, C. and Trohman, R.G. (2006) Narrative Review: Electrocution and Life-Threatening Electrical Injuries. Annals of Intern Medicine, 145, 531-537. http://dx.doi.org/10.7326/0003-4819-145-7-200610030-00011

[11] Celebi, A., Gulel, O., Cicekcioglu, H., Gokaslan, S., Kututcularoglu, G. and Ulusoy, V. (2009) Myocardial Infarction after Electric Shock: A Rare Complication. Cardiology Journal, 16, 362-364.

[12] Lown, B., Neuman, J., Amarasingham, R. and Berkovits, B.V. (1962) Comparison of Alternating Current with Direct Electroshock across the Closed Chest. A merican Journal of Cardiology, 10, 223-233. http://dx.doi.org/10.1016/0002-9149(62)90299-0

[13] Solem, L., Fischer, R.P. and Strate, R.G. (1977) The Natural History of Electrical Injury. Journal of Trauma-Injury Infection \& Critical Care, 17, 487-492. http://dx.doi.org/10.1097/00005373-197707000-00001

[14] Homa, S., Gillam, L.D. and Weyman, A.E. (1990) Electrocardiographic Observations in Survivors of Acute Electrical Injury. Chest, 97, 103-105. http://dx.doi.org/10.1378/chest.97.1.103

[15] Guntheti, B.K., Khaja, S. and Singh, U.P. (2012) Pattern of Injuries due to Electric Current. Journal of Indian Academy of Forensic Medicine, 34, 44-48. 